\title{
Citizen preferences and public goods: comparing preferences for foreign aid and government programs in Uganda
}

\author{
Helen V. Milner $^{1}$ • Daniel L. Nielson ${ }^{2}$. \\ Michael G. Findley ${ }^{3}$
}

Published online: 5 February 2016

(C) The Author(s) 2016. This article is published with open access at Springerlink.com

\begin{abstract}
Different theories about the impact of aid make distinct predictions about citizens' attitudes toward foreign aid in recipient countries. We investigate their preferences toward aid and government projects in order to examine these different theories. Are citizens indifferent between development projects funded by their own government versus those funded by foreign aid donors, as aid capture theory suggests? To address this, in an experiment on a large, representative sample of Ugandan citizens, we randomly assigned the names of funding groups for actual forthcoming development projects and invited citizens to express support attitudinally and behaviorally. We find that citizens are significantly more willing to show behavioral support in favor of foreign aid projects compared to government programs, especially if they already perceive the government as corrupt or clientelist or if they are not supporters of the ruling party. They also trust donors more, think they are more effective, and do not consistently oppose aid conditionality. This experimental evidence is consistent with a theory that we call donor control which sees donors asbeing able to target and condition aid so that it is not fungible with government revenues and thus to be able to better direct it to meet citizens' needs.
\end{abstract}

Electronic supplementary material The online version of this article (doi:10.1007/s11558-016-9243-2) contains supplementary material, which is available to authorized users.

Helen V. Milner

hmilner@princeton.edu

Daniel L. Nielson

dan_nielson@byu.edu

1 Woodrow Wilson School of Public and International Affairs, Princeton University, 431 Robertson Hall, Princeton, NJ 08544, USA

2 Department of Political Science, Brigham Young University, 745 SWKT, Provo, UT 84602, USA

3 Department of Government, University of Texas at Austin, 3.108 BATS, Austin, TX 78712, USA 
Keywords Foreign aid · Public opinion · Clientelism · Corruption · Trust · Aid conditionality · Aid effectiveness · Donor control · Experiment · Aid capture · Uganda

\section{Introduction ${ }^{1}$}

What do citizens in developing countries think about the foreign aid they receive? This paper investigates the perceptions and beliefs of Ugandan citizens toward foreign aid and government development projects. It also measures some of their behavior related to those beliefs. Using a survey experiment with behavioral outcomes, it examines citizen support and willingness to take action for projects managed and financed by foreign donors or the domestic government. There is much debate over the impact of foreign aid on developing countries. Many scholars have tried to answer this by looking at flows of aid and correlating them with various "objective" measures of economic or political development. This important exercise has yielded many, although inconsistent, results about the impact of aid. We are interested in a different element of the aid equation. We want to know what citizens who are likely to have experienced the effects of foreign aid think about it and how much they support it.

Citizens' attitudes may matter just as much as objective outcomes for three reasons. First, attitudes and beliefs may have a strong correlation with how aid projects are actually performing. After all, Ugandans are likely to experience aid and governmentrun projects continually, especially since aid is such an important part of the economy, as we detail later. Second, even if these perceptions do not correlate with objective outcomes, they may be important for politics, policy, and development. Citizens have attitudes and beliefs first and then take actions or not; objective measures of outcomes may not be known to them and are filtered through their beliefs in any case. ${ }^{2}$ Even if we could agree on key objective development indicators - see the debates about using GDP per capita versus the Human Development Index (Srinivasan 1994) - it is not clear that they are as important for motivating citizen behavior as perceptions.

Subjective well-being is now a major element of development policy. Moreover, this is especially true of public goods provision since objective measures of government output are even more underdeveloped. ${ }^{3}$ Other research shows that attitudes and beliefs matter a great deal. For instance, research on happiness - or life satisfaction - demonstrates both that

\footnotetext{
${ }^{1}$ Independent human subjects committees of the Institutional Review Boards at the authors' respective universities completed ethics screenings. Based on a description of the project, clearance to perform the research in Uganda was sought and granted from the Ugandan National Council for Science and Technology and the Ugandan Office of the President. In each of the enumeration areas, the local head of security reviewed the official permissions and approved local enumeration. Subjects were told the research was being conducted by researchers from the United States by name and institution and then consented into the study.

${ }^{2}$ As a major recent study concluded, "there often seems to be a marked distance between standard measures of important socio economic variables like economic growth, inflation, unemployment, etc. and widespread perceptions. In some countries, this gap has undermined confidence in official statistics with a clear impact on the way in which public discourse about the conditions of the economy and necessary policies takes place." (Stiglitz et al. 2009, p. 7)

3 "Governments play an important part in today's economies. They provide services of a "collective" nature, such as security, and of a more "individual" nature, such as medical services and education. These services tend to be large in scale, and have increased considerably since World War II, but, in many cases, they remain badly measured. For a satisfactory measure of economic performance and living standards it is thus important to come to grips with measuring government output." (Stiglitz et al. 2009, pp. 11-12)
} 
it is not closely related to objective indicators but yet has important effects on development. Development is about human flourishing (Sen 1999). Happiness, however, is not necessarily closely correlated with objective indicators of development like, say, income (Easterlin 1973, 1995; Frey and Stutzer 2002; Layard 2005). Yet happiness can affect development, and hence attitudes matter (Kroll 2011). Research on trust is similar. It is not highly correlated with objective indicators of development, but it is essential for fostering development (Zak and Knack 2001; Bjørnskov 2012).

Third, as we detail below, different theories about the impact of aid depend on and make assumptions about citizens' attitudes, beliefs, and behavior. Examining these varying assumptions against evidence might yield a clearer picture about the role of aid. It should help us to understand under what conditions different theories of aid and its effects are more likely to be operative. Perceptions about aid and government projects can inform our theories and provide evidence for (or against) them. Hence, perceptions and revealed preferences matter, not just objective indicators.

Importantly, prior research has rarely asked citizens about aid as opposed to its most relevant alternative: government spending. We thus compare citizens' support or opposition to foreign aid versus government development projects. We then make inferences about the effects of aid vs. government projects on citizens' willingness to take supportive actions that impose personal costs. The present study thus provides data from the first randomized experiment on recipient citizens' attitudinal and behavioral support for foreign aid compared to government-sponsored projects. We also randomly assigned the donor we named from the list of actual sponsors. This enables a precise estimate of the degree to which citizens support projects from some donors over others. As we detail below, there are few meaningful differences across foreign donors, but citizen actions reveal significant differences between foreign aid and government programs.

Exploring the relationship between non-state provision of public goods and government provision is an important area of research. For instance, there is a significant literature on the role of religious groups as alternatives to the state, reflecting on how governments may be affected by public attitudes toward them and these religious groups when both try to provide public goods (Scheve and Stasavage 2006; Cammett and Issar 2010; Cammett and MacLean 2011). A key issue is whether non-state provision of public goods undermines the government. In addition, recent research on foreign aid shows that the comparison between government and foreign aid providers is important. There is some evidence that publics support non-state actors such as donor agencies more than government in public goods provision and that this does not undermine government legitimacy (Sacks 2012; Dietrich and Winters 2015). While in other regions, religious groups may vie with states to provide public goods, in Sub-Saharan Africa the main alternative providers are NGOs and foreign aid donors (Bratton 1989). Hence we examine that comparison by looking at public attitudes and behavior toward government versus aid-funded projects.

We recruited a representative sample of nearly 3600 Ugandan citizens and asked them a battery of demographic and attitudinal survey questions. After the survey, we randomly presented subjects with one of two descriptions of actual pipeline aid projects co-financed by multiple agencies and providing either education or electricity. We randomly assigned the project to have its funder named as one of its actual foreign donors or have no donor named, which the majority of subjects took to be the Ugandan government. Then we invited subjects to express support for the project by survey response, by signing a petition, and by sending an SMS text message. 
The results show that Ugandans overwhelmingly support the development projects regardless of source. But they are significantly more likely to express support, sign the petition, and send the SMS message for projects funded by foreign donors compared to the Ugandan government. Citizens, however, express relative indifference between the foreign donors. For their part, the aid vs. government treatment effects are substantively small for each individual item but, when aggregated into overall indices of support, appear sizable, meaningful, and consistent across outcome measures.

Why would an individual citizen be more supportive of foreign aid projects than government ones? The literature suggests certain conditions under which this is most likely. First, if citizens believe that their government is very corrupt and/or clientelist, then foreign aid - even if problematic - may seem more likely to deliver the public goods they desire. Second, when foreign aid donors have goals beyond purely buying foreign policy concessions from a recipient government, then the donors may condition the use of their funds on development and democracy goals that match those of the public more closely. Third, when aid can be channeled in ways that make it harder for government officials and political leaders to use for clientelist or corrupt purposes, then the public may prefer aid. Conditioning aid and limiting its fungibility may allow donors to bring aid projects more into line with the desires of the public. We expect then that perceptions of corruption and clientelism will be major factors affecting citizen preferences. We also expect partisanship to be an important influence because it is a main channel for clientelism.

We also investigate multiple alternative mechanisms that might explain why Ugandans support aid over government programs, including their education, poverty, media exposure, gender, geographic region, party membership, experience with aid, and concerns about corruption and clientelism. Only the political party affiliation and perceptions of government corruption show significant and consistent results across the behavioral and survey outcomes. ${ }^{4}$ The results imply that citizens prefer foreign donors over domestic agencies because they perceive aid to be less susceptible to corruption and clientelism because aid donors can condition and target funds for projects, as one theory suggests. This is further buttressed by the relative indifference the public shows toward different foreign donors; the fact that the projects are sponsored by foreign donors seems to be the key, regardless of country or international organization of origin.

We also reflect on the likelihood that Ugandans see aid as "free resources" compared to taxes that pose a personal financial burden. We discuss this possibility below and ultimately downgrade its probability in light of more likely alternatives. We further consider the chance that the failure to name the government explicitly in the control condition led to the treatment effects. Extended analysis suggests that, rather than causing treatment effects, this design choice actually decreased the difference between experimental conditions and thus led to understating the effects.

\footnotetext{
${ }^{4}$ Corruption is the use of public power for private gain. Clientelism involves a form of corruption in which political leaders offer goods and services to their constituents in exchange for their political support. Our survey does not distinguish between them. There is good evidence that both occur in developing countries such as Uganda.
} 


\section{The debate and motivation}

Information about preferences and beliefs of citizens in recipient countries like Uganda can help us differentiate between two competing theories of aid, the first we label "aid capture" and the second "donor control." The aid capture and donor control theories rely on different assumptions about the public and donors. Recent work has made the important move of considering aid giving as a process of strategic interaction between donors and recipient governments. But the current debate centers around which group has more influence in this relationship. On the one hand, the aid capture model gives much influence to recipient governments. In this theory, donors give aid to recipients and have little control over how it is used. Sometimes this is because aid is given in exchange for foreign policy concessions and hence is provided to geo-strategically important countries (Bueno de Mesquita and Smith 2007, 2009). In this relationship, aid is very fungible by design. Leaders of recipient governments can use the aid funds as they please. Donors are not willing or able to control how aid is used. Hence, in corrupt and clientelist settings, aid is captured and misused. Analysts have thus likened aid to natural resources in the way resources "curse" developing countries with conflict, autocracy, and poor governance (Morrison 2009; Moyo 2009, p. 59, Morrison 2012).

According to the aid capture theory, the public in the recipient country is the biggest loser in this relationship since aid does not provide public goods, reduce poverty, or increase growth (Bueno de Mesquita and Smith 2009; Moyo 2009). Rather, aid keeps corrupt governments in office longer to pursue undesirable policies (Svensson 2000; Alesina and Weder 2002; Morrison 2009; Briggs 2012; Jablonski 2014). ${ }^{5}$ The public is unwilling or unable in this story to monitor and sanction the government, even though it might do these things for government projects that are funded by taxes (Bräutigam 2000; Smith 2008; Morrison 2009; Gervasoni 2010). Why is the public unable or unwilling to monitor and sanction the government? This question and the answer are often not considered, but it is crucial to the plausibility of the theory. The answer must be either that the public does not know what is going on or knows but does not care. Under these conditions we would not expect the public to perceive any difference between government programs or foreign aid projects. Our data can speak to these conjectures about the public.

In the donor control theory, by contrast, donors are much more influential. Donors are interested in using aid not just for geo-strategic purposes and in exchange for policy concessions, but also for development, reform, and democracy promotion. To this end when dealing with problematic governments, donors are willing and able to condition and target aid in ways that make it much less fungible. Donors understand many of the challenges they face in developing countries and try to act strategically to advance their goals. In contrast to a story emphasizing donor allocation of fungible aid, donors may attach conditions to aid, provide both non-fungible and fungible aid, alter the channel of delivery, and even withhold (or threaten to withhold) aid in response to recipient leader decisions.

Substantial research provides evidence for this view of aid and donors. Bermeo (2010, 2011) shows that Western donors' goals have changed since the end of the Cold War and

\footnotetext{
${ }^{5}$ According to Bueno de Mesquita and Smith (2009), the public in recipient countries should always be worse off with aid than with government projects. Hence one might expect them to prefer government ones to foreign aid. But if aid is fungible, they should not be able to tell the difference between it and government projects and should be indifferent between the two.
} 
that they are now more focused on development and democracy promotion (see also: Dunning 2004). Bermeo demonstrates that donors pursue "strategic development" in deliberately allocating different types of aid to different types of countries. For instance, in weak institutional contexts donors provide aid so that it explicitly targets improvements in government capacity rather than providing narrow benefits to specific leaders. For example, Bermeo (2014, p. 4) presents findings that aid does not inhibit democratization, noting that "aid is not oil. Foreign aid comes from donors and donors have preferences. They also have tools to provide a heterogeneous basket of aid which can look very different from the revenue stream attached to a state-owned enterprise."

Even if aid fails to strengthen institutions or build capacity directly, some literature claims that donors when giving aid - especially for democracy and governance - can find ways around incumbent politicians. Dietrich (2013) shows that donors strategically decide how much aid to provide directly to governments and how much to bypass them. This "circumvention" aid can support opposition parties, watchdog media, and civil society organizations that might effectively demand more accountability. Indeed, some evidence suggests that aid contributes significantly to democratization in recipient governments (Finkel et al. 2007, Aronow et al. 2012).

In strategically targeting and delivering aid, donors provide less fungible aid. As Altincekic and Bearce (2014) argue, aid has never been as fungible as many scholars imply. They point out that the evidence about aid fungibility relies largely on a single paper (Feyzioglu et al. 1998), which found high fungibility only in one sector: agriculture. Moreover, donors have grown less inclined over time to give aid as direct budget support, which is likely easier for elites to capture. Thus, aid - especially aid for projects - may be restricted in ways that stymie recipient politicians' designs.

Foreign aid - especially if it is monitored, has conditions attached to it, or is less fungible - may thus serve more as a public good that politicians struggle to divert to themselves and their allies (Mavrotas and Ouattara 2006). Aid may not be, in fact, similar to other non-tax revenues such as oil. If donors exercise substantial control over aid, then we should expect citizens to strongly support foreign aid and even prefer it to government provided projects, since they can benefit most from aid under these conditions.

A donor's likelihood of adopting these practices depends on several factors. First, the geostrategic importance of the recipient shapes how much the donor will be willing to push for aid to be used for development and democracy promotion. Many studies note that the end of the Cold War had a marked impact on the ability of donors to use aid for development, reform, and democracy (Dunning 2004; Wright 2009; Bearce and Tirone 2010; Bermeo 2010, 2011). Promoting development and democracy is likely to be much closer to the preferences of the public in many poor countries. Once freed from geo-political concerns, donors may use aid in ways that are very consistent with the preferences of citizens in poor countries.

This raises the question of differences among foreign aid donors. It seems likely that some foreign aid donors might be more motivated by geopolitical or domestic reform goals for aid. For instance, the US as a global hegemon might be more attuned to geopolitics than other donors. Or international organizations might give aid for different purposes than individual countries do. Numerous studies of foreign aid conclude that multilateral aid is distinct from bilateral aid. Theoretically, multilateral aid is said to be less politically tied to donor countries and their domestic politics. As Martens, et al. (2002, p. 17) concludes, "Multilateral aid agencies may be somewhat shielded against direct political pressure from their member states." Rodrik (1996) shows some aggregate evidence that supports the argument that 
"multilateral flows are less governed by political considerations than bilateral ones" (Rodrik 1996, p. 176). Other macro-level empirical studies also produce results suggesting that multilateral agencies fund different countries and projects from bilateral ones, and that the former tend to target poorer countries and those with greater needs than those targeted by bilateral agencies (Maizels and Nissanke 1984; Frey and Schneider 1986; Tsoutsoplides 1991; Burnside and Dollar 2000; Neumayer 2003, Girod 2008).

Hence, different aid donors might give aid for different reasons; some may be less preoccupied with strategic interests and more interested in distributing aid for developmental purposes and economic reforms. In one element of the study, then, we randomly assign different foreign aid donors to the public. The funding organizations we included were the World Bank, the African Development Bank, the Government of the United States, the Government of China, a generic "international organization funded by many countries", and a generic "single foreign country." Do publics view donors differently, perhaps favoring multilateral ones?

Additionally, the recipient government's propensity for corruption and clientelism matters; donors do not need to make aid infungible for good governments, which will have the same goals as the donors and can be trusted with the funds. Studies show that targeting of aid and bypassing the government is much more likely when the recipient government is nondemocratic and corrupt. As we know, clientelism and corruption pervade many polities, particularly in poor, developing areas (Wantchekon 2003; Brusco et al. 2004, Keefer 2007; Remmer 2007; Bustikova and Corduneanu-Huci 2011; Hicken 2011; Stokes et al. 2013). Singling out Uganda as a particularly egregious case, van de Walle notes that the typical form in Africa is what he calls "prebendalism," in which elites "unambiguously subvert the rule of law for personal gain" (van de Walle 2007, pp. 52, 57). When geopolitical concerns are not primary for the donor and the recipient is seen as corrupt and clientelist, we expect donor control theory to be most relevant. In the donor control theory then, publics can gain from aid, they should support aid as well as aid conditionality, and they should trust donors more.

Can we use our data to distinguish between the aid capture and donor control theories? Our experiment with citizens goes to the source for the story about how aid is perceived on the ground. If aid is completely fungible with government revenues, then citizens should be indifferent between aid and government projects. If, however, aid is conditioned and targeted toward more public goods provision, then citizens should be more willing to support aid. And yes, citizens do prefer public goods. In our nationally representative survey, $76 \%$ of respondents prefer a project providing more public goods to one with more private benefits ( $24 \%$ ).

We could examine these theoretical propositions directly, but there are three reasons why our experimental approach may be preferred: citizens might not understand what we are asking, they might feel social desirability bias about responding, and this approach would obtain information about attitudes only and not behavior. This latter point is critical and is one reason why a list experiment is not sufficient. Behavior matters and is often more telling than attitudinal outcomes. Our behavioral measures require the respondent to do something that entails costs. Signing a petition is costly since others may see it. And sending an SMS is costly in terms of time and money. Respondents had to remember to send the text, recall the number, take the time to send the message, and pay for its transmission. Our much lower rates of response for the behavioral outcomes make clear that these actions are costly and thus much less likely. In that sense they are a better measure of the intensity of preferences. We can use all of our questions about support for 
aid - i.e., our dependent variables - to create an index measuring not just the direction of preferences but also their intensity.

So we explore whether and to what extent citizens support foreign aid relative to government projects. If donor control theory is applicable, then we might also see particular subgroup effects. Citizens may believe that through monitoring, conditionality, and selectivity, aid agencies may enforce more accountable practices on governments than citizens alone can. But this should matter most when they also believe their own government is corrupt and clientelist. In particular, those groups that perceive significant corruption and clientelism in the government should be most favorable toward aid and least toward the government. With greater donor control, even corrupt and clientelist elites should not be able to capture as much of the aid funds as they would like. In addition, party membership should matter. Those not associated with the governing party should be much more favorable to aid since, unlike government funds biased toward favored constituencies, aid is more likely to be given to their districts as well.

In order to understand citizens' attitudes and behaviors toward development projects, we also examine the most plausible alternative candidates, including their gender, education, poverty, media exposure, experience with aid, and geographic region. But, as detailed below, none of these factors appears to consistently explain their behavior toward aid. Only perceptions of corruption and party membership differentiate Ugandans' attitudes toward foreign donors and government development projects.

Do citizens know enough to have meaningful preferences? Ugandans in our survey knew significantly more about politics and aid than might be expected in a poor country. More than $83 \%$ of respondents could name their MP in an open-ended prompt, and $70 \%$ could name their woman MP. More than two thirds knew that direct foreign aid totaled more than $30 \%$ of the Ugandan budget. Nearly two thirds reported that they listened daily to the radio, where news programs are frequent. Ugandans are reasonably well-informed about key features of politics and aid; thus they possibly possess useful information about foreign assistance.

We therefore consider whether citizens' preferences align better with one of the two major theories about aid. Our experiment can reveal evidence for the following propositions:

1A. To the extent that aid is largely fungible with government revenues, citizens should be indifferent between the two sources of funding for development projects.

1B. When aid is being targeted and conditioned by donors so that it is less fungible and more likely to provide public goods, citizens should be more willing to support and pay higher costs to demonstrate their support for aid projects than government ones.

1C. If multilateral aid donors are less motivated by geopolitical interests than bilateral donors, then the public should be more supportive of multilateral ones.

And they should also evince the following patterns of preferences:

2. Citizens who are not part of the ruling party should be more supportive of foreign aid than are NRM supporters.

3. Citizens who perceive the government to be more corrupt and clientelist should be most supportive of foreign aid. 
4. Citizens should evince greater trust in foreign aid agencies than in their own governmental institutions.

5. Citizens should support conditionality in aid programs.

\section{Research setting: the Ugandan context}

We investigate these conjectures in Uganda, which suffers from serious corruption (Tangri and Mwenda 2001). In 2010 it ranked 129th out of 178 countries in terms of perceptions of corruption according to Transparency International. Its corruption score has been worse than that of the average Sub-Saharan African country for years. It is also heavily aid-dependent; since the 1990s aid, including off-budget sources, has equaled roughly $70 \%$ of Uganda's government expenditures and $15 \%$ of its total GDP.

Freedom House lists Uganda as "partly free," and Polity IV categorizes it as a closed anocracy ( -1 on its 20 -point scale from full autocracy at -10 to full democracy at +10 ). Geddes et al. (2012) code Uganda as a "personalistic regime," and both Hyde and Marinov (2012) and Cheibub et al. (2010) note that after 2006 Uganda began holding competitive elections where other parties were allowed to compete, yet elections were not fully free and fair. Uganda is thus moving toward multiparty democracy.

Yet widespread clientelism in Uganda persists, and it has facilitated the single-party government of the National Resistance Movement (NRM) led by President Museveni to retain power for nearly 30 years (van de Walle 2003, 2007; Muhumuza 2009; Green 2010; Tripp 2010). As one recent study points out, "In Uganda, the ruling NRM has established patronage networks throughout the country through the use of local government. These clientelist networks, while consolidating key sources of support, at the same time undermine governance and erode the viability of institutions and leadership" (Tripp 2010, p. 25).

\section{Research design}

We investigate the attitudes and behavior of 3582 citizens toward foreign aid through a nationally representative experiment (conducted June-August 2012) of recipients' preferences toward different funders. See online appendix and Table A1 for details on the subject pool and sampling details. ${ }^{6}$ In sampling, our primary objective was a politically representative sample, which was largely achieved. We achieved a fairly close match to the 2002 Ugandan census - the latest available at the time of sampling - in terms of other demographic factors; in most categories the study sample was within a few percentage points of the census (see Table A1). These other factors - religion, tribe, and wealth - did not appear, however, to condition the treatment effects reported. As an experiment, the key was achieving balance for covariates across conditions, which randomization checks through regression analysis suggest was accomplished (see Table A2).

Our interventions focus on one type of aid: project aid. Project aid is much more infungible and targeted than budget support. We focus on project aid because it is the most common type, it constitutes the overwhelming monetary share, and it is the most

\footnotetext{
${ }^{6}$ The appendix is available on the Review of International Organizations's website.
} 
visible to citizens. ${ }^{7}$ We acknowledge that project aid and budget-support aid might have different political effects. The findings of Tripp (2013) and Gazibo (2013) in Tanzania and Benin, respectively, suggest that budget-support aid is more corruptible than project aid. In fact, perceptions of increased corruption have led donors to reduce budget support in Benin and Uganda in favor of project aid.

We randomly selected subjects and then randomly assigned actual pipeline project descriptions to them. The projects were co-financed by multiple agencies, which allowed us to manipulate, without active deception, the donor presented to the subjects as well as the type of project: an electricity project and an education project. The experiment incorporated behavioral responses in which subjects could substantiate their stated preferences for development projects by undertaking actions that imposed personal costs. Enumerators invited the subjects to support the project by signing a petition and sending an SMS message, among other attitudinal statements of support or opposition. ${ }^{8}$

Our framing question was: "The Electricity Sector Development Project will improve the reliability of and increase access to electricity. One major aspect of the project is to extend electricity to those who do not yet have access to it. The project may require your community to provide funding for maintenance in the future. [This project will be funded by [FUNDER]]. How much would you support this project?" See the online appendix for education project description.

We included the sentence about future expenses to increase the respondents' sense that supporting the project might be costly. Given that aid may be perceived as "free money" whereas government programs may imply increased taxes, we were concerned that offering a project without any noted costs might lead all subjects to support it. In the "Discussion" section below we consider the implications of this design choice.

The funding organizations we randomly assigned were the World Bank, the African Development Bank, the Government of the United States, the Government of China, "an international organization funded by many countries", "a single foreign country," and No Donor, in which we omitted the sentence indicating which agency was funding the project. In this last case we assumed that recipients would associate this condition with their own domestic government spending. We elected not to name the government explicitly out of fear that generalized paranoia toward government might bias responses. Considerable evidence from the Afrobarometer suggests that our design concerns here were well placed. ${ }^{9}$ We made this choice in good faith seeking to avoid social desirability bias, but we acknowledge that explicitly naming the government in an alternative condition would have presented a

\footnotetext{
${ }^{7}$ According to the AidData information base, which is the largest repository of aid statistics, between 2000 and 2012 Uganda received 157 budget support grants and loans summing to $\$ 3.2$ billion. Over the same period, the country was host to 16,019 aid projects summing to $\$ 24.5$ billion in total aid. Budget-support aid in Uganda constitutes $1 \%$ of the count, but $13 \%$ of total Ugandan aid. This is roughly on par with the rest of SubSaharan Africa, which received 3811 budget support grants and loans for $\$ 57.5$ billion in relation to 352,839 projects that totaled $\$ 615$ billion. Budget support in the region thus comprised $1 \%$ of the count, but $9 \%$ of the money (Tierney et al. 2011).

${ }^{8}$ Manipulation checks, asked many survey items later, show that subjects recalled the type of project and the type of donor in most cases ( $89 \%$ for project and $63 \%$ for donor). Technically, this question captures the attentiveness of the subject, rather than whether the manipulation worked. But attentiveness to the manipulation is a necessary condition for concluding that donor or type of project had an effect on the dependent variables.

${ }^{9}$ In round 5 of Afrobarometer done in 2012, the same year as our study, $50 \%$ of the Ugandan respondents said they did not feel completely free to say whatever they believe, and $1 / 3$ said they felt some kind of pressure about whom to vote for. Moreover, $65 \%$ admitted fear of being intimidated in election campaigns.
} 
cleaner contrast to the aid condition. Nevertheless, as we detail in the "Discussion" section below, this design decision actually worked in favor of the null hypothesis positing no difference between experimental conditions. Detailed analysis suggests that the treatment effects would have been substantially larger had we actually named the government explicitly.

We have six dependent variables. Four of these were attitudinal; they asked whether the respondent supported the project, whether they would tell of their support to their local village council leader, whether they would sign a petition in support, and whether they would send a supportive SMS message. For the two behavioral outcomes, we invited subjects to sign a paper petition and send an SMS text message. If subjects agreed to sign, they were presented with the petition and enumerators recorded whether or not they actually signed. If subjects agreed to send an SMS message, they were given a slip of paper with the SMS number and asked to send a text later that day. SMS texts cost Ugandans between 50 and $130 \mathrm{USh}$, so the text represented an actual cost to the subjects that they did not expect to recover. Given the low weekly incomes in Uganda, for the vast majority of subjects the cost likely appeared non-trivial. While these variables tap similar preferences toward the projects, they do so in different ways and with different levels of preference intensity. We designed them so that they would indicate increasing levels of support as measured by the costs (real or hypothetical) associated with each action. This enables us to use all of these variables combined together in an index. In addition to these six outcome measures, we asked numerous questions about citizens' reasons for supporting the projects.

We strove for more general results by including two different types of projects and six different types of donors, including multilateral and bilateral aid donors. Neither of these two dimensions seemed to matter to the public on average. We found no significant differences between the projects or the aid donors; hence we pool all of the data. In addition, we asked numerous attitudinal and behavioral questions to measure preferences. The combination of attitudinal and behavioral outcomes is rare and captures the intensity of preferences as well.

\section{Foreign donor vs. Government provision results}

\subsection{Descriptive background}

In the survey, we find strong support for foreign aid. Eighty-one percent of subjects thought aid should be increased a lot in contrast to $1 \%$ who thought it should be decreased a lot. The proportion that thought aid should be increased at all versus decreased at all was $93 \%$ versus less than $3 \%$. The support for aid was even higher (95\%) when we asked about aid directed to the subject's district. Moreover, 67, 71, and $66 \%$ thought aid had a positive or very positive effect on the Ugandan economy, the central government, and local administrations, respectively. A smaller proportion, however - only $42 \%$ - thought it had a positive effect on individuals like themselves.

Yet a key way to assess aid is to ask how it compares to other policies that affect the living standards of the poor, especially government programs. When we asked Ugandans which entity they thought could most effectively carry out the project, the largest percentage named a foreign aid donor $(31 \%)$. The next most popular were NGOs $(27 \%)$. But the least effective in respondents' minds were the local and national Ugandan governments (10\% and $15 \%$, respectively). Many Ugandans thus see aid and aid organizations as positive factors in their national context. 


\subsection{Experimental results}

Hypothesis 1A and 1B: citizens should be indifferent between or more willing to support and pay higher costs to demonstrate their support for aid than government projects Relative to government-sponsored programs, individuals were more likely to give verbal support for aid. When we asked subjects if they were willing to sign a petition or send a text, their attitudinal responses were positive and significantly in favor of aid compared to government programs for all outcomes, except willingness to sign, as the upper portion of Table 1 shows. When considering the behavioral responses, in particular, we see significant and consistent differences in the expressed likelihood that citizens will take actions imposing personal costs to support foreign aid relative to domestic government projects.

Overall, stated support for these projects, no matter the funding group, is high: $77 \%$ strongly support the foreign-funded projects compared to $73.5 \%$ in the domestic government control condition. Scoring strong support as 1 and the other response categories 0 , the difference of $3.5 \%$ is statistically significant in a difference-in-means test at the 0.1 level $(p=.094)$. When we ask subjects if they are willing to tell their local village leaders that they support the project, the mean for those in the aid condition is 0.94 , while the mean for the government provision condition is 0.91 , which is significantly lower statistically $(p=0.021)$.

In the behavioral outcomes in Table 1, subjects are significantly more likely to take action to demonstrate their support for the foreign aid initiatives over government projects. Among those assigned a foreign donor, $80.3 \%$ actually signed the petition compared to $76.6 \%$ in the control condition. The difference was statistically significant

Table 1 Experimental results: individual DVs

\begin{tabular}{lllllll}
\hline & $\begin{array}{l}\text { Strong } \\
\text { Support }\end{array}$ & $\begin{array}{l}\text { Tell } \\
\text { Support }\end{array}$ & $\begin{array}{l}\text { Willing to } \\
\text { Sign }\end{array}$ & $\begin{array}{l}\text { Signed } \\
\text { Petition }\end{array}$ & $\begin{array}{l}\text { Willing to } \\
\text { SMS }\end{array}$ & $\begin{array}{l}\text { Sent } \\
\text { SMS }\end{array}$ \\
\hline $\begin{array}{l}\text { All respondents } \\
\text { Control/Gov't. }\end{array}$ & 0.73 & 0.91 & 0.82 & 0.77 & 0.59 & 0.02 \\
N & 528 & 520 & 528 & 538 & 538 & 202 \\
Aid & 0.77 & 0.94 & 0.83 & 0.80 & 0.64 & 0.05 \\
N & 3007 & 2967 & 3008 & 3017 & 3017 & 1143 \\
Difference & $0.03 *$ & $0.03^{* *}$ & 0.02 & $0.04 *$ & $0.04 *$ & $0.02^{*}$ \\
T-test & 1.68 & 2.31 & 0.83 & 1.88 & 1.92 & 1.91 \\
$P$-value & 0.094 & 0.021 & 0.405 & 0.060 & 0.056 & 0.057 \\
\hline
\end{tabular}

Positive differences mean aid is preferred to government funding. Note that if a subject did not want to sign the petition (third column) we still presented them the possibility of signing (fourth column). The higher Ns for willingness to SMS in the fifth column (e.g., 538 and 3017) are a result of subject refusals to answer the petition questions (where corresponding Ns are lower: 528 and 3008) but willingness to answer those that followed. Also, the Ns decrease in the "Sent SMS" condition because we only calculate Sent SMS for subjects owing phones. Two-tailed statistical significance

$* * * p<0.01$

$* * p<0.05$

${ }^{*} p<0.10$ 
$(p=0.060)$. In addition, when we asked respondents if they were willing to send an SMS telling of their support, a significantly larger percentage responded yes in the foreign aid condition than in the government condition: 0.64 versus $0.59(p=0.056)$.

Finally, the proportion of subjects with cell phones that actually sent the SMS text message was nearly double (4.9\%) in the aid condition compared to the control $(2.5 \%)$. This difference between the aid treatments and the government condition is also statistically significant at the 0.1 level $(p=0.057)$, and this holds for subjects perceiving government corruption and subjects who passed the manipulation check. Of course, in both conditions the proportion actually sending texts is small, perhaps suggesting that citizens were willing to pay fewer tangible costs to support the project. But it may also indicate the difficulty of the task: subjects had to recall their promise to send a text, recover the slip of paper with the number, and actually send the SMS. The statistical differences between subjects' expressions of willingness to take action and their actual behavior underscore the importance of measuring action rather than merely attitudes.

These treatment effects are modest. This is understandable given both the very strong need Ugandans perceive for the education and electricity projects presented and the ceiling effects this creates in our data. The treatment effects would be larger if, as discussed below, the $37.5 \%$ of subjects in the control condition who believed the named control projects came from foreign donors instead attributed them to the government. The control condition makes the treatment effects smaller than they would have been with a control that explicitly named the government. Still, the consistent treatment effects for aid projects - even substantively small effects - suggest the value that citizens place on foreign sources of assistance over government programs.

We also aggregated the different dependent variables into an index (Project support index). We wanted to measure overall levels of support or opposition to aid versus government programs. And we crafted the survey instrument so that each dependent variable represented a further step in a chain of increasingly costly actions showing support or opposition. The variables measure different aspects of their support for aid and have increasingly costly (real or hypothetical) actions associated with them. An additive index gives a clearer picture of the overall levels and intensity of individual support for the projects. Since all of the dependent variables are dichotomous, our index simply sums them. Missing values are treated as 0 , but respondents who did not respond to any of the DVs are dropped. The minimum value for this variable is 0 and the maximum is 6 . In the appendix, we provide the identical data analysis for each of the six dependent variables and for principal components analysis (PCA) that aggregates the dependent variables in different ways. All of them point in the same direction and support our main findings.

In Table 2 we present the results from this aggregated index. They show that Ugandans very significantly prefer foreign aid projects to government funded ones $(p=0.004)$. Moreover, they are substantially more likely to pay higher costs to demonstrate their support for the aid. The results for Project support index strengthen when restricting the sample to those passing the manipulation check. ${ }^{10}$ The change in

\footnotetext{
${ }^{10}$ We also conducted principal components analysis and report those results in Appendix Table A5. The PCA results are more problematic since they had a hard time handling the fact that many did not have cell phones and thus could not text; hence in it all the people without cells had to be coded as having not texted or be missing entirely. And this is not what their lack of action really meant. So the PCA is less accurate as a measure than the other index.
} 
Table 2 Experimental results: Project support index
Project support index

\begin{tabular}{ll}
\hline All respondents & \\
Gov't. & 3.78 \\
$\mathrm{~N}$ & 538 \\
Aid & 3.99 \\
$\mathrm{~N}$ & 3017 \\
Difference & $0.216^{* * *}$ \\
T-test & 2.88 \\
$P$-value & 0.004 \\
Passed Manipulation Check & \\
Gov't. & 3.54 \\
$\mathrm{~N}$ & 357 \\
Aid & 4.16 \\
$\mathrm{~N}$ & 1893 \\
Difference & $0.619 * * *$ \\
T-test & 6.42 \\
$P$-value & 0.000 \\
\hline Positive differences mean that the second score is larger than the first \\
score, implying aid is preferred to government funding. Two-tailed \\
statistical significance \\
$* * * p<0.01$ \\
$* * p<0.05$ \\
$* p<0.10$
\end{tabular}

support between the control and treatment conditions (relative to the treatment group mean) is also appreciable: $5.4 \%$ for all respondents and between 11 and $15 \%$ for those passing the manipulation check.

Hypothesis 1C. If multilateral aid donors are less motivated by geopolitical interests than bilateral donors, then the public should be more supportive of multilateral ones While we expected that the Ugandan public might prefer aid from multilateral donors, we did not find consistent evidence for this in the data. As Table 3 shows, we see no significant differences among the donors in the public's eyes. Here we compare the means for our dependent variable indicating levels and intensity of support for the project by different aid donors. In part we think this is because the donors do not differ that much. Uganda is not that important of a geostrategic asset that bilateral donors such as the US are likely to let the government have free rein over the aid funds. And our interviews with several of the donors made clear that they have similar views about the probity of the government; and indeed they were all-except China-involved in sanctioning it in the corruption scandal in 2012. Moreover, each of them monitors and channels the aid funds, although often in very different ways. In this case, it seems unlikely that donors would be willing to give up substantial control. Hence we do not see the public demonstrating very different views of the different donors. 
Table 3 T-test of foreign donors: Project support index as dependent variable

\begin{tabular}{lrllllll}
\hline & Mean & World Bank & ADB & US & China & Multilateral & Bilateral \\
& & 3.994 & 3.992 & 4.020 & 4.023 & 3.936 & 3.994 \\
\hline World Bank & 3.994 & - & & & & \\
ADB & 3.992 & $0.002[0.98]$ & - & & \\
US & 4.020 & $-0.026[0.78]$ & $-0.028[0.77]$ & - & \\
China & 4.023 & $-0.030[0.75]$ & $-0.032[0.73]$ & $-0.004[0.97]$ & - \\
Multilateral & 3.936 & $0.058[0.53]$ & $0.056[0.54]$ & $0.084[0.37]$ & $0.088[0.34]$ & - \\
Bilateral & 3.994 & $-0.000[0.99]$ & $-0.002[0.98]$ & $0.025[0.78]$ & $0.029[0.75]$ & $-0.058[0.52]$ & - \\
\hline
\end{tabular}

Value of differences in means in the matrix cells. $P$-values of t-tests of the difference in mean in square brackets below

\subsection{Possible mechanisms as supported by subgroup analysis}

Why do Ugandan citizens have a stronger preference for foreign aid relative to domestic programs? The aid treatment may have had stronger effects on some subsets of subjects than others, and this may allow us to understand the source of their preferences. Given that we found a preference for aid over government projects, we expect two conditions to be important: partisanship and perceptions of corruption and clientelism. The other categories in which we might look for subgroup effects include gender, education, poverty, media exposure, geographic region, experience with aid, and political connections. Most of the subgroup effects are either not statistically significant or not significant in consistent ways that might be predicted from prior theory. The two subgroups we focus on, however, are important and significant as shown in Table 4 party membership and perceptions of clientelism and corruption. First, we display the results for Project support index as in Table 2 above, and then we display the multilevel regression results for the subgroups. And in Appendix Tables A6 and A7, we present the results for PCA and the separate DVs.

\subsection{Relationship to the dominant ruling party, NRM}

Hypothesis 2: Citizens who are not part of the ruling party should be more supportive of foreign aid than are NRM supporters. Party membership is important in Uganda because the dominant party is the main vehicle for corruption and clientelism (Greene 2010; Tripp 2010). ${ }^{11}$ Interestingly, subjects who did not identify with the ruling National Resistance Movement were significantly more likely to express strong support for aid projects over the government condition (Table 4). This provides some evidence that subjects who find themselves outside the government party - i.e., outside the main clientelist networks - were more supportive of aid over government programs. This result is consistent with the possibility that being outside the governing regime inclines citizens to favor aid, as aid agencies may constrain the government's tendencies toward clientelism.

\footnotetext{
${ }^{11}$ The correlation between perceptions of corruption and NRM affiliation is very low, -0.16 . Large percentages of both believe corruption is present (NRM: 69\%; Non-NRM: 84\%).
} 
Table 4 Subgroup effects

DV: Project support index

\begin{tabular}{llll}
\hline $\begin{array}{l}\text { Subgroup } \\
\text { NRM supporter }\end{array}$ & Aid & Govt & Diff \\
$\quad$ Subgroup N & 1705 & 307 & \\
$\quad$ Score & 4.09 & 4.03 & 0.06 \\
Not NRM supporter & & & \\
$\quad$ Subgroup N & 1147 & 195 & $0.36^{* * *}$ \\
$\quad$ Score & 3.91 & 3.54 & \\
Low corruption & & & -0.10 \\
$\quad$ Subgroup N & 738 & 136 & \\
Score & 4.04 & 4.14 & \\
High corruption & & & \\
$\quad$ Subgroup N & 2279 & 402 & \\
Score & 3.98 & 3.65 & \\
\hline Two-tailed statistical significance & & \\
$* * * p<0.01$ & & & \\
$* * p<0.05$ & & & \\
$* p<0.10$ & & &
\end{tabular}

We also estimate regression models to examine the impact of partisanship. Since this variable is not randomly distributed, we check to see if the results hold up when we control for other important factors. As Table 5 below shows, the results are consistently strong. Using mixed-level models to control for any grouping of the data at various subnational levels, we see that when controlling for any level-either constituency, district or region - the treatment effect is evident. This is shown in positive and significant coefficients for treatment*NRM and treatment*non-NRM, which are compared to the base group of those receiving the government condition and being nonNRM. In addition, the comparative effect shown in Table 4 above is also evident. The treatment for non-NRM is significant and positive when compared to those in the government condition for non-NRM citizens. And this is different from the NRM case, where both the treated and the ones in the government condition are not significantly different from one another in their attitudes toward aid. These regression results controlling for other relevant factors then corroborate our findings above in Table 4.

\subsection{Perceptions of government corruption \& clientelism}

Hypothesis 3: Citizens who perceive the government to be more corrupt and clientelist should be more supportive of foreign aid. The results for the subgroup analysis in which we divided subjects according to their perceptions of government clientelism and corruption provide even stronger evidence (Table 4). We asked subjects to choose between similar statements about how foreign aid funds and domestic government funds are allocated. Respondents strongly believed that aid dollars were more likely than domestic government funds to go to the poorest and neediest than to 
Table 5 Multivariate results for NRM: Project support index as dependent variable

\begin{tabular}{|c|c|c|c|c|}
\hline & OLS & $\begin{array}{l}\text { Mixed: } \\
\text { constituency }\end{array}$ & $\begin{array}{l}\text { Mixed: } \\
\text { district }\end{array}$ & $\begin{array}{l}\text { Mixed: } \\
\text { region }\end{array}$ \\
\hline Gov X NRM & $\begin{array}{l}0.512 * * * \\
(0.145)\end{array}$ & $\begin{array}{l}0.531 * * * \\
(0.144)\end{array}$ & $\begin{array}{l}0.544 * * * \\
(0.135)\end{array}$ & $\begin{array}{l}0.516^{* * *} \\
(0.065)\end{array}$ \\
\hline Treat X non-NRM & $\begin{array}{l}0.333 * * \\
(0.132)\end{array}$ & $\begin{array}{l}0.336^{* *} \\
(0.131)\end{array}$ & $\begin{array}{l}0.351 * * * \\
(0.126)\end{array}$ & $\begin{array}{l}0.334 * * * \\
(0.077)\end{array}$ \\
\hline Treat X NRM & $\begin{array}{l}0.491 * * * \\
(0.128)\end{array}$ & $\begin{array}{l}0.511 * * * \\
(0.135)\end{array}$ & $\begin{array}{l}0.526 * * * \\
(0.135)\end{array}$ & $\begin{array}{l}0.496 * * * \\
(0.072)\end{array}$ \\
\hline Corruption & $\begin{array}{l}-0.088 \\
(0.056)\end{array}$ & $\begin{array}{l}-0.108^{*} \\
(0.057)\end{array}$ & $\begin{array}{l}-0.100 \\
(0.061)\end{array}$ & $\begin{array}{l}-0.088 \\
(0.085)\end{array}$ \\
\hline Education & $\begin{array}{l}0.064 * * * \\
(0.007)\end{array}$ & $\begin{array}{l}0.067 * * * \\
(0.007)\end{array}$ & $\begin{array}{l}0.066^{* * *} \\
(0.008)\end{array}$ & $\begin{array}{l}0.064 * * * \\
(0.009)\end{array}$ \\
\hline Media exposure & $\begin{array}{l}0.020^{* * *} \\
(0.008)\end{array}$ & $\begin{array}{l}0.016^{* *} \\
(0.008)\end{array}$ & $\begin{array}{l}0.021 * * * \\
(0.007)\end{array}$ & $\begin{array}{l}0.020 * * * \\
(0.005)\end{array}$ \\
\hline Poverty & $\begin{array}{l}0.103 * * * \\
(0.032)\end{array}$ & $\begin{array}{l}0.128 * * * \\
(0.044)\end{array}$ & $\begin{array}{l}0.114 * * \\
(0.048)\end{array}$ & $\begin{array}{l}0.104^{*} \\
(0.062)\end{array}$ \\
\hline Male & $\begin{array}{l}0.091 * \\
(0.050)\end{array}$ & $\begin{array}{l}0.094 * * \\
(0.040)\end{array}$ & $\begin{array}{l}0.084 * * * \\
(0.031)\end{array}$ & $\begin{array}{l}0.092 * * * \\
(0.027)\end{array}$ \\
\hline Eastern region & $\begin{array}{l}0.628 * * * \\
(0.065)\end{array}$ & $\begin{array}{l}0.605 * * * \\
(0.131)\end{array}$ & $\begin{array}{l}0.555^{* * *} \\
(0.145)\end{array}$ & \\
\hline Western region & $\begin{array}{l}0.295 * * * \\
(0.068)\end{array}$ & $\begin{array}{l}0.336 * * * \\
(0.085)\end{array}$ & $\begin{array}{l}0.311^{* * *} \\
(0.079)\end{array}$ & \\
\hline Central region & $\begin{array}{l}-0.137^{*} \\
(0.079)\end{array}$ & $\begin{array}{l}-0.056 \\
(0.148)\end{array}$ & $\begin{array}{l}-0.080 \\
(0.159)\end{array}$ & \\
\hline Constant & $\begin{array}{l}2.512 * * * \\
(0.190)\end{array}$ & $\begin{array}{l}2.435 * * * \\
(0.264)\end{array}$ & $\begin{array}{l}2.431 * * * \\
(0.241)\end{array}$ & $\begin{array}{l}2.705^{* * *} \\
(0.314)\end{array}$ \\
\hline \multicolumn{5}{|l|}{ Random effects } \\
\hline $\operatorname{sd}($ cons $)$ & & $\begin{array}{l}0.324 * * * \\
(0.050)\end{array}$ & $\begin{array}{l}0.249 * * * \\
(0.030)\end{array}$ & $\begin{array}{l}0.289 * * * \\
(0.069)\end{array}$ \\
\hline sd(Residual) & & $\begin{array}{l}1.368 * * * \\
(0.037)\end{array}$ & $\begin{array}{l}1.382 * * * \\
(0.055)\end{array}$ & $\begin{array}{l}1.408^{* * *} \\
(0.102)\end{array}$ \\
\hline $\mathrm{N}$ & 3308 & 3308 & 3308 & 3308 \\
\hline $\begin{array}{l}\text { Sig level of Diff. Gov X NRM } \\
\text { and Treat X NRM }\end{array}$ & 0.799 & 0.761 & 0.778 & 0.688 \\
\hline
\end{tabular}

Excluded group is Gov. X Non-NRM respondents. The first 3 coefficients test the difference between the labeled group and the Gov. X Non-NRM group. Significance level of Diff. Gov X NRM and Treat X NRM is test of whether the difference in the coefficients of Gov X NRM and Treat X NRM is different from zero. Column 1 contains robust standard errors; columns 2 through 4 use standard errors clustered at the multilevel level

political cronies. We asked whether they agreed more with statement 1 or 2: "Statement 1: Aid from a [foreign donor] most helps the friends or allies of the donor that is giving the money. Or Statement 2: Aid from a [foreign donor] most helps the neediest people in your country." We also asked them to choose between these two statements about 
their own government: "Statement 1: The current government leaders take government money to benefit themselves and their friends. Statement 2: The current government leaders use government money to benefit everyone in the country." 12 On a scale of 1 (agreeing with statement 1 the most) to 5 (agreeing with statement 2 the most), the mean for the foreign aid question was significantly greater than that for the government (3.20 vs. $1.96, p=0.000) .{ }^{13}$ Ugandans thus believe that domestic government programs are far more politicized and corrupt than foreign aid projects.

If our conjecture is correct, we should find substantial differences in support for aid between the two subgroups precisely because aid dollars are not as susceptible to corruption and clientelism. Analyzing these groups separately, we found that the treatment effects in favor of aid reported in Tables 1 and 2 hold even more strongly for the subgroup of subjects perceiving high levels of corruption. For the subgroup that did not perceive corruption and clientelism in the government, the effects of the aid treatment are not statistically significant. Those who believe the government is clientelist and corrupt are significantly more likely to prefer foreign aid.

We also estimated regression models to examine the impact of perceptions of corruption. Since this variable is not randomly distributed, we check to see if the results hold up when we control for other important factors. As Table 6 below shows, the results are consistently strong. Using mixed-level models to control for any grouping of the data at various subnational levels, we see that there are treatment effects since both those perceiving low and high corruption when treated differ from those not treated. And the analysis shows that there are significant differences in support for aid between those treated and perceiving high corruption and those not treated and perceiving high corruption, with the treated ones being more supportive of aid. And it demonstrates that this significant difference does not exist for those perceiving low government corruption. This regression supports our claims from the analysis in Table 4.

\subsection{Trust in domestic government vs international organizations}

\section{Hypothesis 4: Citizens should evince greater trust in foreign aid agencies than in} their own governmental institutions. Citizens also trust the foreign aid agencies and international organizations more than their main domestic political institutions. We asked about their levels of trust in their local village council leaders (LC III), provincial governors (LC V), their members of parliament (MP), parliament overall, the dominant NRM as a party, and the president. For international institutions, we asked about their level of trust in the IMF, USAID, the World Bank, UNDP, and African Development Bank. In nearly all comparisons in Table 7 there was a statistically significant difference between the domestic and the international institution; bold entries indicate significant differences at the 0.05 level. ${ }^{14}$ While most comparisons are strongly significant $(\mathrm{t}$ -

\footnotetext{
$\overline{{ }^{12}}$ More than three-fourths of subjects agreed or strongly agreed with statement 1 .

${ }^{13}$ Results restricted to those who passed the manipulation checks are similar: the mean for aid was significantly greater than that for government ( 3.15 vs. $1.84, p=0.0000)$.

${ }^{14}$ The Trust question for the international institutions was only asked of people who said they had heard of the institution.
} 
Table 6 Multivariate results for corruption: Project support index as dependent variable

\begin{tabular}{|c|c|c|c|c|}
\hline & OLS & $\begin{array}{l}\text { Mixed: } \\
\text { constituency }\end{array}$ & $\begin{array}{l}\text { Mixed: } \\
\text { district }\end{array}$ & $\begin{array}{l}\text { Mixed: } \\
\text { region }\end{array}$ \\
\hline Gov X Low corruption & $\begin{array}{l}0.409 * * * \\
(0.140)\end{array}$ & $\begin{array}{l}0.412 * * * \\
(0.147)\end{array}$ & $\begin{array}{l}0.427 * * * \\
(0.147)\end{array}$ & $\begin{array}{l}0.408 * * * \\
(0.098)\end{array}$ \\
\hline Treat X Low corruption & $\begin{array}{l}0.244 * * * \\
(0.095)\end{array}$ & $\begin{array}{l}0.263 * * * \\
(0.086)\end{array}$ & $\begin{array}{l}0.265^{* * * *} \\
(0.092)\end{array}$ & $\begin{array}{l}0.244 * \\
(0.131)\end{array}$ \\
\hline Treat X High corruption & $\begin{array}{l}0.214 * * \\
(0.085)\end{array}$ & $\begin{array}{l}0.210^{* * *} \\
(0.081)\end{array}$ & $\begin{array}{l}0.224 * * * \\
(0.082)\end{array}$ & $\begin{array}{l}0.214 * * * \\
(0.079)\end{array}$ \\
\hline NRM & $\begin{array}{l}0.211 * * * \\
(0.054)\end{array}$ & $\begin{array}{l}0.228 * * * \\
(0.060)\end{array}$ & $\begin{array}{l}0.230 * * * \\
(0.053)\end{array}$ & $\begin{array}{l}0.214 * * * \\
(0.029)\end{array}$ \\
\hline Education & $\begin{array}{l}0.063 * * * \\
(0.007)\end{array}$ & $\begin{array}{l}0.067 * * * \\
(0.008)\end{array}$ & $\begin{array}{l}0.065^{* * *} \\
(0.008)\end{array}$ & $\begin{array}{l}0.063 * * * \\
(0.010)\end{array}$ \\
\hline Media exposure & $\begin{array}{l}0.020 * * * \\
(0.008)\end{array}$ & $\begin{array}{l}0.016^{* *} \\
(0.008)\end{array}$ & $\begin{array}{l}0.021 * * * \\
(0.007)\end{array}$ & $\begin{array}{l}0.019 * * * \\
(0.005)\end{array}$ \\
\hline Poverty & $\begin{array}{l}0.101 * * * \\
(0.032)\end{array}$ & $\begin{array}{l}0.126^{* * * *} \\
(0.044)\end{array}$ & $\begin{array}{l}0.112 * * \\
(0.047)\end{array}$ & $\begin{array}{l}0.102 \\
(0.062)\end{array}$ \\
\hline Male & $\begin{array}{l}0.092 * \\
(0.050)\end{array}$ & $\begin{array}{l}0.095 * * \\
(0.040)\end{array}$ & $\begin{array}{l}0.085 * * * \\
(0.031)\end{array}$ & $\begin{array}{l}0.093 * * * \\
(0.027)\end{array}$ \\
\hline Eastern region & $\begin{array}{l}0.636^{* * * *} \\
(0.065)\end{array}$ & $\begin{array}{l}0.613 * * * \\
(0.130)\end{array}$ & $\begin{array}{l}0.564 * * * \\
(0.144)\end{array}$ & \\
\hline Western region & $\begin{array}{l}0.296^{* * *} \\
(0.068)\end{array}$ & $\begin{array}{l}0.335^{* * *} \\
(0.084)\end{array}$ & $\begin{array}{l}0.312 * * * \\
(0.079)\end{array}$ & \\
\hline Central region & $\begin{array}{l}-0.136^{*} \\
(0.079)\end{array}$ & $\begin{array}{l}-0.057 \\
(0.148)\end{array}$ & $\begin{array}{l}-0.078 \\
(0.159)\end{array}$ & \\
\hline Constant & $\begin{array}{l}2.537 * * * \\
(0.165)\end{array}$ & $\begin{array}{l}2.446^{* * * *} \\
(0.242)\end{array}$ & $\begin{array}{l}2.451 * * * \\
(0.234)\end{array}$ & $\begin{array}{l}2.733 * * * \\
(0.418)\end{array}$ \\
\hline \multicolumn{5}{|l|}{ Random effects } \\
\hline $\operatorname{sd}($ cons $)$ & & $\begin{array}{l}-1.130 * * * \\
(0.154)\end{array}$ & $\begin{array}{l}-1.396^{* * *} \\
(0.123)\end{array}$ & $\begin{array}{l}-1.233 * * * \\
(0.239)\end{array}$ \\
\hline sd(Residual) & & $\begin{array}{l}0.314 * * * \\
(0.027)\end{array}$ & $\begin{array}{l}0.323 * * * \\
(0.040)\end{array}$ & $\begin{array}{l}0.342 * * * \\
(0.072)\end{array}$ \\
\hline $\mathrm{N}$ & 3308 & 3308 & 3308 & 3308 \\
\hline $\begin{array}{l}\text { Sig of Diff. Gov X Low corrupt and } \\
\text { Treat X Low corrupt }\end{array}$ & 0.189 & 0.280 & 0.251 & 0.000 \\
\hline
\end{tabular}

Excluded group is Gov. X High Corruption respondents. The first 3 coefficients test the difference between the labeled group and the Gov. X High Corruption group. "Sig level of Diff. Gov X low corrupt and Treat X low corrupt" is a test of whether the difference in the coefficients of Gov X low corrupt and Treat X low corrupt is different from zero. Column 1 contains robust standard errors; columns 2 through 4 use standard errors clustered at the multilevel level

scores ranging from approximately 7 to approximately 25), absolute values of average trust for both international and domestic institutions are moderately high. In general, for both international and domestic actors, the average trust levels bookend the value of 3 (where the scale ranges from 1 to 4), which 
Table 7 Trust Levels for Domestic Versus International Institutions

\begin{tabular}{|c|c|c|c|c|c|c|}
\hline \multirow[t]{3}{*}{ Domestic } & \multirow[t]{3}{*}{ Means } & \multicolumn{5}{|c|}{ International } \\
\hline & & IMF & USAID & WB & UNDP & AFDB \\
\hline & & 3.07 & 3.38 & 3.34 & 3.29 & 3.15 \\
\hline \multirow[t]{2}{*}{ LC V } & 2.92 & 0.144 & 0.459 & 0.420 & 0.369 & 0.227 \\
\hline & & $(\mathbf{0 . 0 3 5})$ & $(0.030)$ & $(0.025)$ & $(0.037)$ & $(0.033)$ \\
\hline \multirow[t]{2}{*}{ LC III } & 3.07 & -0.000 & 0.314 & 0.275 & 0.224 & 0.082 \\
\hline & & $(0.033)$ & $(0.028)$ & $(0.024)$ & $(0.035)$ & $(0.031)$ \\
\hline \multirow[t]{2}{*}{ MP } & 3.02 & 0.049 & 0.364 & 0.324 & 0.273 & 0.132 \\
\hline & & $(0.035)$ & $(0.030)$ & $(0.025)$ & $(0.037)$ & $(0.033)$ \\
\hline \multirow[t]{2}{*}{ Parliament } & 3.03 & 0.031 & 0.346 & 0.307 & 0.256 & 0.114 \\
\hline & & $(0.033)$ & $(0.028)$ & $(0.024)$ & $(0.034)$ & $(0.031)$ \\
\hline \multirow[t]{2}{*}{ NRM } & 2.89 & 0.176 & 0.491 & 0.451 & 0.400 & 0.259 \\
\hline & & $(0.040)$ & $(0.033)$ & $(0.028)$ & $(0.042)$ & $(0.037)$ \\
\hline \multirow[t]{2}{*}{ President } & 3.06 & 0.003 & 0.318 & 0.279 & 0.228 & 0.086 \\
\hline & & $(0.038)$ & $(0.032)$ & $(0.027)$ & $(0.040)$ & $(0.035)$ \\
\hline
\end{tabular}

Mean trust in italics; cells report differences in means with standard errors in parentheses underneath. Bold entries indicate significant differences at the 0.05 level. Positive differences mean that the international institution is more trusted than the domestic one

means that international and domestic actors both enjoy reasonably high levels of trust.

Only when the IMF was compared to some domestic institutions were there statistically insignificant results. This difference is interesting because it shows that not all foreign organizations are automatically preferred to domestic ones and that publics can differentiate among them. It provides evidence against the notion that subjects respond as they do because of positive affect toward "foreign" and negative affect toward "domestic" and instead hold more sophisticated views of development project funders. The IMF acts differently than the other aid providers in that it intervenes during crises and is associated with austerity policies in bad times. Overall, Ugandans support most developmentgranting institutions, but evince a statistically stronger preference for international institutions that provide development finance in comparison to their own government.

\subsection{Views of aid conditionality}

Hypothesis 5: Citizens should support conditionality in aid programs. Finally, we asked respondents about their views of aid conditionality. Conventional wisdom assumes that the vast majority of recipients do not like conditions imposed on their aid flows. But if aid agencies act as a brake on government corruption, then citizens might actually be accepting of conditionality. We asked subjects to choose between two statements: Statement 1: "The conditions or requirements set by [an individual foreign government 
or an international institution] in order for Uganda to receive aid are unfair and hurt Uganda. Or Statement 2: "The conditions or requirements set by [an individual foreign government or an international institution] in order for Uganda to receive aid help Uganda to reform and become a better country." Roughly $50 \%$ of subjects approve of conditionality by aid agencies, which is much higher than conventional wisdom suggests. This appears consistent with the argument advancing aid conditionality as a counterweight to corruption. Moreover, when we analyze the experimental effects sub-grouped on whether people believe conditionality helps or harms in Table 8 , subjects believing conditionality helps are significantly more likely to support aid, whereas those believing conditionality is harmful are less likely to support aid. Appendix Table A8 shows similar results for the individual and PCA-generated dependent variables.

In sum, the survey and experimental data show that the public is very supportive of foreign aid, does not distinguish among foreign aid donors, but is not indifferent between aid and government funding of development projects. They do not see the two as identical and aid funds as completely fungible with government revenues. Furthermore, citizens are not unaware of their political situation nor are they passive. Large percentages correctly answered all of the political knowledge questions we posed, and sizeable percentages were willing to take somewhat costly actions like signing a petition and sending an SMS. In sum, we find support for five of our six hypotheses. Although they do not perceive differences among foreign aid donors, Ugandans do support foreign aid projects more than domestic government programs; they trust the foreign aid agencies more than their own government; a significantly higher proportion supports conditionality than conventional wisdom suggests; and those believing the government to be corrupt and clientelist are most supportive of foreign aid, as are those outside the dominant ruling party. They also believe foreign aid agencies are more effective than government-controlled ones.

\section{Discussion}

The set up and analysis of the experiment required numerous design and analysis decisions. Here we elaborate on two key design choices - the costs of the project and

Table 8 Conditionality subgroup effects for those receiving the aid condition

\begin{tabular}{lll} 
DV: Project support index & & \\
\hline Subgroup & $\mathrm{N}$ & Score \\
Aid & & \\
Cond Help & 1358 & 4.15 \\
Cond Harm & 1263 & 3.93 \\
Diff & $-0.23^{* * *}$ \\
\hline Two-tailed statistical significance & \\
$* * * p<0.01$ & \\
$* * p<0.05$ & \\
$* p<0.10$ &
\end{tabular}


the control condition - as well as describe robustness checks for the key treatment effects.

\subsection{Design considerations}

In the experimental prompt, we added a statement about the potential future costs associated with receiving the project. We were concerned that citizens might view foreign aid as free resources that they would of course support. To understand the implications of the cost condition, we conducted additional tests, which cast doubts on the possibility that citizens were making the decision simply because they perceived it to be free. First, we conducted follow up tests of whether subjects were sensitive to the inclusion of the statement about costs. Second, we considered the distribution of taxpayers with an explicit test of whether taxpayers and non-taxpayers behaved differently. And third we note that the between-subjects design provides a comparison of projects identical in their statements of costs and still can observe the differences in the various experimental conditions. Across these additional tests, the evidence supports the inferences we have made in the discussion above. See Appendix for fuller discussion of each of these additional points.

A second design objection might be that the government was not named in the control condition. We were motivated to avoid social desirability in responses if the government was explicitly named in the control. Citizens might fear government reactions and so always claim support for the government projects. To assess what citizens perceived when they viewed the control condition, we conducted a follow-up survey with 460 randomly selected individuals. We found that the majority of subjects did in fact interpret the control condition as the government $(52 \%$ and $51 \%$ for the education and electricity projects, respectively). A portion of subjects in the follow-up study, however, attributed the control condition to a foreign donor: $37 \%$ and $38 \%$ for education and electricity, respectively (the remainder answered "do not know" or refused to answer). While a more direct comparison might have been preferable, if it had been free from social desirability bias, this misattribution actually works in favor of the null hypothesis of no treatment effects. In the appendix we show formally that the results are biased against the identification of treatment effects, and thus the effects we uncover and report above actually understate the extent of the differences. See Appendix for complete discussion.

\subsection{Robustness}

As described above, we conducted a series of tests beyond the intent-to-treat results. When we exclude subjects who failed the manipulation check, which followed the verbal and behavioral outcome measures, the results are strengthened, as shown in the lower portion of Table 2 and in the middle portion of Appendix Table A3. Hence when limiting the sample to those who understood the treatment, we find strong support for our argument across all six dependent variables. Here, the treatment effects are substantively much larger.

However, rather than report the results for those that pass the manipulation check only, we report on all subjects. Dropping subjects affects the representativeness of the overall sample (Berinsky et al. 2014). We thus consider additional tests: the complier 
average causal effect (CACE) and a selection model. To calculate CACE (Gerber and Green 2012), we use a 2-stage least squares model. Because we have information from the manipulation check that helps us understand better what people perceived when they received the control or treatment, we can use that check as a measure of compliance. We use assignment to treatment as an instrument to predict compliance (perceptions in the manipulation check), which in turns predicts level of support for aid vs. government assistance. ${ }^{15}$ The results are reported in the lower portion of Appendix Table A3 and are qualitatively the same as those in the baseline intent-to-treat model.

In the Appendix, we also show the results from final robustness tests. We estimated Heckman selection models for each of the outcomes (See Table A8). All of the coefficients for the aid treatment remain statistically significant. The results are strengthened further when we interact the treatment with the manipulation check as shown in Appendix Table A9 and Appendix Figure A1. The marginal effects are all statistically significant in the expected direction, with the aid treatment causing significantly greater attitudinal and behavioral support for the projects for those subjects passing the manipulation check. Treatment effects for subjects failing the manipulation check were negative and often significant.

\section{Conclusions}

We investigate the perceptions and preferences of citizens toward foreign aid and government development projects. These matter greatly for citizen action and can help us distinguish among theories about the impact of aid. First, it is notable how positively Ugandans view foreign aid. Large majorities like aid, want more of it, and think it is best for public goods provision. Second, if aid is fungible with government revenues and the government can do with it as they please, then we should see no difference between citizen preferences for aid or government projects. They should be indifferent between the two sources since they are in effect the same. But they are not indifferent, and they are not lacking political knowledge or just politically passive, as the first theory about aid suggests. If however they perceive aid to be conditioned and targeted by donors toward goals they desire like the provision of public goods, then citizens may well prefer aid. While we expected that citizens might perceive different foreign donors as more likely to control their aid, we found little difference among the donors. Moreover, we expected them to hold a series of other views as well, as we detail in our hypotheses. Looking at such individual-level evidence informs the microfoundations that can be supported in macro-level claims about aid. Our data do not seem consistent with the aid capture theory that foreign aid and government spending on development projects are highly fungible and subject to the same levels of clientelism and corruption. Rather they strongly support the donor control theory.

\footnotetext{
$\overline{15}$ The manipulation check allows $u s$ to distinguish those that received the treatment and thought it was the treatment (complier-treated), received control and thought it was control (complier-control), received treatment but thought control (never-takers), and received control but thought treatment (always takers). Some respondents answered "Do not Know" in the manipulation check rather than offer the name of a specific donor or "None" for control. As no specific entity was named in the control condition, we classified the "Do not Know" responses along with the "None".
} 
Our data is from a single point in time and long dependence on aid could have led to worse government performance now. The micro evidence does not disprove these macro arguments. But citizens do not perceive aid and government projects in the same way. Although Ugandans desperately want the type of public goods projects we ask them about, they are even more supportive when they are foreign aid ones than government ones. Those who are not members of the ruling party and thus are less likely to benefit from clientelism strongly prefer foreign aid projects; as do those who perceive corruption and clientelism in the government. On average citizens have more trust in foreign aid donors than in domestic institutions. They are not opposed to aid conditionality. All of these results are more consistent with the theory of aid that gives donors a strong capacity to direct aid and channel it more towards projects the public wants. Citizens' perceptions and preferences then can inform us about our theories of aid.

It is possible that these results are confined to Uganda. It is a highly aid dependent country with well-known corruption and clientelism problems. It is not a vital geo-strategic ally for the major aid donors. All of these factors make donors more influential and more likely to want to condition and target aid. And this may help explain why the public does not see major difference between the donors. However, similar results are likely to obtain in other developing countries that have weak political institutions and limited democracy. As countries grow richer and more democratic, our findings might weaken. Government programs in these latter types of countries are probably less subject to clientelism and corruption; research shows that increasing democracy increases public goods provision and overall welfare (Baum and Lake 2003; Stasavage 2005a, 2005b). If so, this is likely to improve citizens' perceptions of government programs and lessen the contrast to foreign aid projects.

Corruption and clientelism are serious problems in poor, weakly institutionalized democratizing polities. Development projects run by governments may succumb to such pressures. Citizens, at least in Uganda, appear to believe that aid agencies, even with poor monitoring and conditionality, are better equipped to deliver public goods like electricity and education that they want. Donors under certain conditions may be able and willing to make aid work, especially compared to the next best alternative.

Disclosures This study was funded by Princeton University and Brigham Young University. The authors declare that they have no conflict of interest. The authors have received formal approval for their research involving human participants by their universities' Institutional Review Boards.

Open Access This article is distributed under the terms of the Creative Commons Attribution 4.0 International License (http://creativecommons.org/licenses/by/4.0/), which permits unrestricted use, distribution, and reproduction in any medium, provided you give appropriate credit to the original author(s) and the source, provide a link to the Creative Commons license, and indicate if changes were made.

\section{References}

Alesina, A., \& Weder, B. (2002). Do corrupt governments receive less foreign aid? American Economic Review, 92(4), 1126-1137.

Altincekic, C., \& Bearce, D.H. (2014). Why there should be no political foreign aid curse. World Development, 64(12), 18-32. 
Aronow, P. M., Allison, C., \& Marinov, N. (2012). The effects of aid on rights and governance: Evidence from a natural experiment. Working Paper, Yale University, New Haven. August 2, 2012. Retrieved from http:// papers.ssrn.com/sol3/papers.cfm?abstract_id=2199131

Baum, M. A., \& Lake, D. A. (2003). The political economy of growth: democracy and human capital. American Journal of Political Science, 47(2), 333-347.

Bearce, D. H., \& Tirone, D. C. (2010). Foreign aid effectiveness and the strategic goals of donor governments. Journal of Politics, 72(3), 837-851.

Berinsky, A. J., Margolis, M. F. \& Sances, M. W. (2014) Separating the shirkers from the workers? Making sure respondents pay attention on self-administered surveys. American Journal of Political Science, 58(3), $739-753$.

Bermeo, S. B. (2010). Development and strategy: Aid allocation in an interdependent world. Duke University, Durham, NC. September 22, 2010. Retrieved from http://papers.ssrn.com/sol3/papers.cfm?abstract_id=1681104

Bermeo, S. B. (2011). Foreign aid and regime change: a role for donor intent. World Development, 39(11), 2021-2031.

Bermeo, S. B. (2014). Aid is not oil: Donor preferences, heterogeneous aid, and the aid-democratization relationship. Working Paper, Duke University. July 2014

Bjørnskov, C. (2012). How does social trust affect economic growth? Southern Economic Journal, 78(4), 1346-1368.

Bratton, M. (1989). The politics of government-NGO relations in Africa. World Development, 17(4), $569-587$.

Bräutigam, D. (2000). Aid dependence and governance. Stockholm: Almqvist \& Wiksell International.

Briggs, R. C. (2012). Electrifying the base? Aid and incumbent advantage in Ghana. The Journal of Modern African Studies, 50(04), 603-624.

Brusco, V., Nazareno, M., \& Stokes, S. C. (2004). Vote buying in Argentina. Latin American Research Review, 39(2), 66-88.

Bueno de Mesquita, B., \& Smith, A. (2007). Foreign aid and policy concessions. Journal of Conflict Resolution, 51(2), 251-284.

Bueno de Mesquita, B., \& Smith, A. (2009). A political economy of aid. International Organization, 63(2), 309-340.

Burnside, C., \& Dollar, D. (2000). Aid, policies and growth. American Economic Review, 90(4), 847-868.

Bustikova, L., \& Corduneanu-Huci, C. (2011). Clientelism, state capacity and economic development: A cross-national study. Unpublished manuscript, Duke University, Durham, NC. June 21, 2011

Cammett, M. C., \& MacLean, L. M. (2011). Introduction: the political consequences of non-state social welfare in the global south. Studies in Comparative International Development, 46(1), 1-21.

Cammett, M., \& Issar, S. (2010). Bricks and mortar clientelism: sectarianism and the logics of welfare allocation in Lebanon. World Politics, 62(3), 381-421.

Cheibub, J. A., Gandhi, J., \& Vreeland, J. R. (2010). Democracy and dictatorship revisited. Public Choice, 143(1-2), 67-101.

Dietrich, S. (2013). Bypass or engage? Explaining donor delivery tactics in foreign aid allocation. International Studies Quarterly, 57(4), 698-712.

Dietrich, S., \& Winters, M. S. (2015). Foreign aid and government legitimacy. Journal of Experimental Political Science, 2(2), 164-171.

Dunning, T. (2004). Conditioning the effects of aid: cold war politics, donor credibility, and democracy in Africa. International Organization, 58(2), 409-423.

Easterlin, R. A. (1973). Does money buy happiness? The Public Interest, 30, 3-10.

Easterlin, R. A. (1995). Will raising the incomes of all increase the happiness of all? Journal of Economic Behavior \& Organization, 27(1), 35-47.

Feyzioglu, T., Swaroop, V., \& Zhu, M. (1998). A panel data analysis of the fungibility of foreign aid. World Bank Economic Review, 12(1), 29-58.

Finkel, S. E., Pérez-Liñán, A., \& Seligson, M. A. (2007). The effects of U.S. foreign assistance on democracy building, 1990-2003. World Politics, 59(3), 404-439.

Frey, B. S., \& Schneider, F. (1986). Competing models of international lending activity. Journal of Development Economics, 20(2), 225-245.

Frey, B. S., \& Stutzer, A. (2002). The economics of happiness. World Economics, 3(1), 1-17.

Gazibo, M. (2013). Beyond electoral democracy: foreign aid and the challenge of deepening democracy in Benin. In D. Resnick, N. van de Walle (Eds.), Democratic trajectories in Africa: Unravelling the impact of foreign aid (pp. 228-255). Oxford: Oxford University Press.

Geddes, B., Wright, J., \& Frantz, E. (2012). New data on autocratic breakdown and regime transitions. Unpublished manuscript, UCLA; Pennsylvania State University; Bridgewater State University, Los Angeles, CA; University Park, PA; Bridgewater, MA. September 8, 2012 
Gerber, A. S., \& Green, D. P. (2012). Field experiments: design, analysis, and interpretation. New York: W. W. Norton.

Gervasoni, C. (2010). A rentier theory of subnational regimes: fiscal federalism, democracy, and authoritarianism in the argentine provinces. World Politics, 62(2), 302-340.

Girod, D. M. (2008). Cut from the Same Cloth? Multilateral Vs. Bilateral Aid. Prepared for the Annual Conference of the International Political Economy Society, Philadelphia. November 2008.

Green, E. D. (2010). Patronage, district creation, and reform in Uganda. Studies in. Comparative International Development (SCID), 45(1), 83-103.

Greene, K. F. (2010). The political economy of authoritarian single-party dominance. Comparative Political Studies, 43(7), 807-834.

Hicken, A. (2011). Clientelism. Annual Review of Political Science, 14(1), 289-310.

Hyde, S. D., \& Marinov, N. (2012). Which elections can be lost? Political Analysis, 20(2), 191-210.

Jablonski, R. S. (2014). How aid targets votes: the impact of electoral incentives on foreign aid distribution. World Politics, 66(02), 293-330.

Keefer, P. (2007) Governance and Economic Growth. In L. A. Winters, S. Yusuf (Eds.), Dancing with giants: China, India, and the global economy (pp. 211-242). Washington, DC; Singapore: The World Bank; Institute of Policy Studies.

Kroll, C. (2011). Measuring progress and well-being: Achievements and challenges of a new global movement. International Political Analyses, Friedrich Ebert Stiftung, Berlin. October 2011. Retrieved from http://ibrary.fes.de/pdf-files/id/ipa/08509.pdf.

Layard, P. R. G. (2005). Happiness: lessons from a New science. New York: Penguin Press.

Maizels, A., \& Nissanke, M. K. (1984). Motivations for aid to developing countries. World Development, 12(9), 879-900.

Martens, B., Mummert, U., Murrell, P., \& Seabright, P. (2002). The institutional economics of foreign aid. New York: Cambridge University Press.

Mavrotas, G., \& Ouattara, B. (2006). Aid disaggregation and the public sector in aid-recipient economies: some evidence from Côte d'Ivoire. Review of Development Economics, 10(3), $434-451$.

Morrison, K. M. (2009). Oil, nontax revenue, and the redistributional foundations of regime stability. International Organization, 63(1), 107-138.

Morrison, K. M. (2012). What can we learn about the "resource curse" from foreign aid? World Bank Research Observer, 27(1), 52-73.

Moyo, D. (2009). Dead aid: Why aid is not working and how there is a better way for Africa. New York: Farrar, Straus and Giroux.

Muhumuza, W. (2009). From fundamental change to no change: the national resistance movement (NRM) and democratization in Uganda. Les Cahiers d'Afrique de l'Est, 41, 21-42.

Neumayer, E. (2003). The determinants of aid allocation by regional multilateral development banks and united nations agencies. International Studies Quarterly, 47(1), 101-122.

Remmer, K. L. (2007). The political economy of patronage: expenditure patterns in the argentine provinces, 1983-2003. Journal of Politics, 69(2), 363-377.

Rodrik, D. (1996). Why Is There Multilateral Lending? In M. Bruno, B. Pleskovic (Eds.), Annual World Bank Conference on Development Economics, 1995 (pp. 167-193). Washington, DC: International Bank for Reconstruction and Development.

Sacks, A. (2012). Can donors and non-state actors undermine citizens' legitimizing beliefs? Policy Research Working Paper No. 6158, The World Bank, Washington, DC. August 2012. Retrieved from http://elibrary. worldbank.org/doi/pdf/10.1596/1813-9450-6158

Scheve, K., \& Stasavage, D. (2006). The political economy of religion and social insurance in the United States, 1910-1939. Studies in American Political Development, 20(02), 132-159.

Sen, A. K. (1999). Commodities and capabilities. New Delhi: Oxford University Press.

Smith, A. (2008). The perils of unearned income. Journal of Politics, 70(3), 780-793.

Srinivasan, T. N. (1994). Human development: a new paradigm or reinvention of the wheel? American Economic Review, 84(2), 238-243.

Stasavage, D. (2005a). Democracy and education spending in Africa. American Journal of Political Science, 49(2), 343-358.

Stasavage, D. (2005b). The role of democracy in Uganda's move to universal primary education. The Journal of Modern African Studies, 43(01), 53-73.

Stiglitz, J. E., Sen, A., \& Fitoussi, J. P. (2009). Report by the commission on the measurement of economic performance and social progress. Commission on the Measurement of Economic Performance and Social Progress, Paris. September 14, 2009. Retrieved from http:/www.stiglitz-sen-fitoussi.fr/documents/ rapport_anglais.pdf. 
Stokes, S. C., Dunning, T., Nazareno, M., \& Brusco, V. (2013). Brokers, Voters, and Clientelism: The Puzzle of Distributive Politics. Cambridge University Press.

Svensson, J. (2000). Foreign aid and rent-seeking. Journal of International Economics, 51(2), 437-461.

Tangri, R., \& Mwenda, A. (2001). Corruption and cronyism in Uganda's privatization in the 1990s. African Affairs, 100(398), 117-133.

Tierney, M. J., Nielson, D. L., Hawkins, D. G., Roberts, J. T., Findley, M. G., Powers, R. M., Parks, B., Wilson, S. E., \& Hicks, R. L. (2011). More dollars than sense: refining our knowledge of development finance using AidData. World Development, 39(11), 1891-1906.

Tripp, A. M. (2010). Museveni's Uganda: paradoxes of power in a hybrid regime. Boulder: Lynne Rienner Publishers.

Tripp, A. M. (2013). Donor assistance and political reform in Tanzania. In D. Resnick, N. van de Walle (Eds.), Democratic trajectories in Africa: Unravelling the impact of foreign aid (pp. 170-199). Oxford: Oxford University Press.

Tsoutsoplides, C. (1991). The determinants of the geographical allocation of EC aid to the developing countries. Applied Economics, 23(4A), 647-658.

van de Walle, N. (2003). Presidentialism and clientelism in Africa's emerging party systems. The Journal of Modern African Studies, 41(2), 297-321.

van de Walle, N. (2007) Meet the new boss, same as the old boss? The evolution of political clientelism in Africa. In H. Kitschelt, S. Wilkinson (Eds.), Patrons, clients and policies: Patterns of democratic accountability and political competition (pp. 50-67). Cambridge: Cambridge University Press.

Wantchekon, L. (2003). Clientelism and voting behavior: evidence from a field experiment in Benin. World Politics, 55(3), 399-422.

Wright, J. (2009). How foreign aid can foster democratization in authoritarian regimes. American Journal of Political Science, 53(3), 552-571.

Zak, P. J., \& Knack, S. (2001). Trust and growth. The Economic Journal, 111(470), 295-321. 